\title{
PENERAPAN MODEL PROBLEM BASED LEARNING DENGAN MEDIA RAK TELUR RAINBOW UNTUK MENINGKATKAN HASIL BELAJAR MATEMATIKA PADA SISWA KELAS II SDN AJUNG 02 JEMBER (SEMESTER II TAHUN PELAJARAN 2017-2018)

\author{
Hartini
}

\author{
SDN Ajung 02 Kecamatan Ajung Jember \\ email: ajung02hartini@gmail.com
}

\begin{abstract}
Abstrak: Masalah penelitian ini adalah hasil belajar matematika siswa kelas II SDN Ajung 02 masih rendah, terbukti dari 22 siswa presentasi ketuntasan belajar siswa sebesar $27 \%$ dengan rata-rata 59,77 padahal kelas dinyatakan tuntas jika memperoleh $85 \%$. Respon dan aktivitas belajar siswa juga masih rendah terbukti dengan kurang aktifnya siswa saat pembelajaran. Maka peneliti menerapkan model Problem Based Learning (PBL) dengan media rak telur rainbow. Penelitian dilaksanakan di kelas II SDN Ajung 02 Kecamatan Ajung Kabupaten Jember Provinsi Jawa Timur dengan jenis penelitian yang digunakan adalah Penelitian Tindakan Kelas (PTK) dengan 3 siklus yang setiap siklus terdiri dari tahapan perencanaan, pelaksanaan, observasi dan refleksi. Teknik pengumpulan data yang digunakan adalah observasi, tes hasil belajar dan angket pada setiap akhir siklusnya, alat pengumpulan data dilakukan dengan menggunakan lembar panduan observasi, soal-soal tes dan angket. Terbukti pada siklus I persentase hasil belajar siswa $46 \%$, siklus II $68 \%$ dan pada siklus III menjadi $86 \%$. Dan persentase hasil aktivitas belajar pada siklus I sebesar 67\%, siklus II sebesar 75\%, siklus III sebesar 86,5 serta hasil respon siswa pada siklus I sebesar 56,6\%, siklus II sebesar 66,67\%, dan siklus III sebesar 71,6\%.
\end{abstract}

Kata Kunci: Problem Based Learning, Media Rak Telur Rainbow, Hasil Belajar

\begin{abstract}
The problem of this study is that the mathematics learning outcomes of class II students at SDN Ajung 02 are still low, as evidenced by the 22 students who presented their learning completeness by $27 \%$ with an average of 59.77 even though the class was declared complete if it received $85 \%$. The response and learning activities of students are also still low as evidenced by the lack of active students during learning. So the researcher applied the Problem Based Learning (PBL) model with rainbow egg rack media. The research was conducted in class II SDN Ajung 02 Ajung Subdistrict, Jember Regency, East Java Province. The type of research used was Classroom Action Research (CAR) with 3 cycles in which each cycle consisted of stages of planning, implementation, observation and reflection. Data collection techniques used were observation, learning outcomes tests and questionnaires at the end of each cycle, data collection tools were carried out using observation guide sheets, test questions and questionnaires. Evidenced in the first cycle the percentage of student learning outcomes was $46 \%$, cycle II $68 \%$ and in cycle III to $86 \%$. And the percentage of learning activities in the first cycle is $67 \%$, cycle II is $75 \%$, cycle III is 86.5 and the results of student responses in the first cycle are $56.6 \%$, cycle II is $66.67 \%$, and cycle III is $71,6 \%$.
\end{abstract}

Keywords: Problem Based Learning, Rainbow Egg Rack Media, Learning Outcomes 


\section{PENDAHULUAN}

Mata pelajaran matematika perlu diberikan kepada semua siswa mulai dari sekolah dasar untuk membekali siswa dengan kemampuan berfikir logis, analitis, sistematis, kritis, dan kreatif, serta kemampuan bekerja sama. Kompetensi tersebut diperlukan agar siswa dapat memiliki kemampuan memperoleh, mengelola, dan memanfaatkan informasi untuk bertahan hidup pada keadaan yang selalu berubah, tidak pasti, dan kompetitif.

Matematika sebagai salah satu mata pelajaran di SD yang perlu mendapat perhatian khusus sebab matematika dapat mempersiapkan siswa agar dapat menggunakan pola pikir matematika dalam kehidupan sehari-hari dan dalam pembelajaran berbagai ilmu. Pembelajaran matematika hendaknya dapat memberikan dorongan kepada siswa untuk dapat menimbulkan minat belajar. Oleh karena itu, pelajaran matematika tidak akan menjadi pelajaran yang membosankan bagi siswa tetapi menjadi pelajaran yang menyenangkan. Pelajaran matematika yang menyenangkan diharapkan secara tidak langsung dapat diterapkan oleh siswa dalam kehidupan sehari-hari. Meskipun demikian kebanyakan siswa masih menganggap matematika sebagai mata pelajaran yang sulit dan membosankan. Anggapan yang demikian tentu saja sangat berpengaruh terhadap minat dan hasil belajar siswa dalam mata pelajaran matematika.

Berdasarkan hasil observasi proses pembelajaran matematika pada materi perkalian dan pembagian, terlihat guru tidak menggunakan media, model atau strategi yang tepat. Guru lebih cenderung menggunakan metode ceramah dan menekankan kepada penugasan, jadi membuat siswa merasa bosan dengan pelajaran matematika. Di dalam pembelajaran matematika materi perkalian dan pembagian ini, siswa lebih ditekankan pada tugas-tugas dan cara belajarnya menghafal. Sehingga tidak dipungkiri ada beberapa siswa yang kurang menyukai dan memahami pelajaran matematika. Terbukti nilai ketuntasan siswa kelas II SDN Ajung 02 pada materi perkalian dan pembagian hanya 27\% dan rata-rata kelas 59,77 padahal kelas dinyatakan tuntas apabila telah memperoleh Ketuntasan Kelas Maksimal (KKM) $70 \%$.

Alternatif pemecahan masalah pada pembelajaran matematika diantaranya adalah memilih model dan media pembelajaran yang tepat. Salah satu cara untuk menyelesaikan permasalahan pada materi perkalian dan pembagian pada siswa kelas II SDN Ajung 02 Jember yaitu menggunakan model pembelajaran Problem Based Learning (PBL) dengan media yang cocok digunakan adalah rak telur rainbow. Pemilihan model dan media 
tersebut berlandaskan pertimbangan tujuan pembelajaran, karakteristik materi, karakteristik siswa, dan fasilitas pendukung lainnya.

Keunggulan media rak telur rainbow adalah siswa lebih tertarik untuk mengikuti pembelajaran dan aktif bekerja sama dengan siswa lainnya. Media ini membantu siswa untuk mengetahui tentang konsep perkalian dan pembagian, dan pembelajaran jadi lebih menyenangkan, bermakna dan tidak membuat siswa bosan.

Media Rak telur rainbow peneliti gunakan karena rak telur lebih kontekstual dan sudah dikenal siswa dalam kehidupan sehari-hari. Sehingga media ini peneliti jadikan penelitian tindakan kelas yang berjudul "Penerapan Model Problem Based Learning Dengan Media Rak Telur Rainbow Untuk Meningkatkan Hasil Belajar Siswa Pada Mata Pelajaran Matematika di SDN Ajung 02".

\section{METODE PENELITIAN}

Lokasi penelitian adalah kelas II SDN Ajung 02 Kecamatan Ajung Kabupaten Jember yang dilaksanakan pada semester II bulan Maret sampai bulan Mei 2018. Subjek dalam penelitian ini adalah siswa kelas II SDN Ajung 02 Kecamatan Ajung Kabupaten Jember Semester II Tahun Pelajaran 2017/2018. Jumlah siswa kelas II SDN Ajung 02 adalah 15 siswa, yang terdiri dari 5 siswa laki-lakidan 10 siswa perempuan.

Penelitian ini dirancang untuk meningkatkan hasil belajar Matematika materi perkalian dan pembagian bilangan pada siswa kelas II semester II SDN Ajung 02 Kecamatan Ajung Kabupaten Jember Tahun Pelajaran 2017/2018, penelitian tindakan kelas dilakukan melalui empat langkah utama yang saling berkaitan, yaitu:

a. Perencanaan (planning)

Perencanaan merupakan kegiatan merancang secara rinci tentang apa dan bagaimana tindakan yang akan dilakukan. PTK untuk pengembangann profesi guru, kegiatan ini berupa menyiapkan bahan ajar, menyiapkan rencana mengajar, merencakan bahan untuk pembelajaran, serta menyiapkan hal lain yang diperlukan dalam proses pembelajaran.

\section{b. Tindakan (acting)}

Tindakan kegiatan ini dalam PTK. Bagi guru, tindakan ini berupa penerapan model atau cara mengajar yang baru. Pada PTK untuk pengembangan profesi guru, tindakan dilakukan selama 3 siklus. 


\section{ELSE (Elementary Schuol Education Journal)}

Volume 3 Nomor 1 Februari 2019

P-ISSN: 2581-1800 E-ISSN: 2597-4122

Email: else@um-surabaya.ac.id

c. Pengamatan(observing)

Pengamatan merupakan tindakan pengumpulan informasi yang akan dipakai untuk mengetahui apakah tindakan yang dilakukan telah berjalan sesuai dengan rencana yang diharapkan. Pengamatan dapat berupa pengumpulan data melalui observasi, tes, kuisoner, dan lain- lainnya.

d. Refleksi (reflecting)

Refleksi bertujuan untuk mengetahui apa yang kurang pada pelaksanaan tindakan yang telah dilakukan. Hasil refleksi digunakan untuk melakukan perbaikan pada perencanaan di tahapan (siklus) berikutnya.

Teknik pengumpulan data yang digunakan dalam penelitian ini adalah dokumentasi, wawancara, tes, observasi, dang angket. Analisis data yang digunakan untuk aktivitas belajar siswa, hasil belajar dan ketuntasan belajar menggunakan rumus persentase dan rata-rata.

\section{HASIL DAN PEMBAHASAN}

Berdasarkan hasil observasi yang sudah dilakukan, peneliti menemukan bahwa metode dan model pembelajaran khususnya pada mata pelajaran matematika yang dilakukan di kelas II SDN Ajung 02 masih monoton dan kurang adanya variasi. Serta kurangnya penggunaan media pembelajaran yang tepat sesuai dengan materi yang akan diajarkan, sehingga siswa merasa bosan, jenuh dan tidak berminat mengikut kegiatan belajar mengajar. Maka dari itu guru kelas melakukan penelitian dengan mencoba menerapkan model Problem Based Learning dengan media Rak telur rainbow untuk meningkatkan hasil belajar siswa materi perkalian dan pembagian bilangan pada siswa kelas II SDN Ajung 02 Kecamatan Ajung Kabupaten Jember Tahun Pelajaran 2017/2018.

Pembahasan hasil pembelajaran pada bagian ini akan diuraikan mengenai pembahasan data penilaian yang telah diperoleh. Data ini diperoleh dari tindakan pra siklus, pelaksanaan siklus I, siklus II, dan siklus III. Pembahasan data yang dilakukan meliputi: 1) ketuntasan aktivitas belajar sisw, 2) nilai rata-rata hasil belajar siswa, 3) ketuntasan hasil belajar siswa, 4) angket (respon siswa). Uraian selengkapnya sebagai berikut. 


\section{ELSE (Elementary School Education Journal) \\ Volume 3 Nomor 1 Februari 2019 \\ P-ISSN: 2581-1800 E-ISSN: 2597-4122 \\ Email: else@um-surabaya.ac.id}

1. Aktivitas Siswa

Berdasarkan hasil pra siklus aktivitas belajar siswa masih belum aktif maka peneliti menggunakan model Problem Based Learning, dan diterapkan pada pembelajaran matematika kelas II SDN Ajung 02 Kecamatan Ajung Kabupaten Jember Tahun Pelajaran 2017/2018.

Hasil observasi yang dilakukan oleh 2 observer dalam penerapan model Problem Based Learning (PBL) dengan media Rak telur rainbow juga menunjukkan adanya peningkatan aktivitas belajar siswa. Nilai aktivitas belajar siswa pada siklus I diperoleh nilai rata-ratanya adalah 37,6 dengan persentase $67 \%$ dalam kategori cukup. Hal ini dibuktikan dengan masih banyaknya siswa yang tidak berani bertanya kepada guru, keberanian siswa mengemukakan pendapat juga masih rendah dan masih banyak siswa yang tidak mau berdiskusi untuk memecahkan suatu masalah. Kondisi seperti ini terjadi karena masih belum terbiasanya siswa dalam mengikuti kegiatan pembelajaran model Problem Based Learnig (PBL) dengan media Rak telur rainbow. Sesuai kondisi tersebut, peneliti mempersiapkan dengan matang pembelajaran pada siklus II agar dapat meningkatkan aktivitas belajar.

Adapun hasil observasi pada aktivitas belajar siswa pada siklus II meningkat menjadi baik, dengan perolehan rata-ratanya adalah 41,8 dengan persentase $75 \%$. Selisih peningkatan aktivitas belajar antara siklus I dengan siklus II sebesar $8 \%$. Hal ini dibuktikan dengan masih adanya siswa yang belum berani bertanya kepada guru, belum mampu mengungkapkan pendapatnya saat berdiskusi dengan kelompok kerjanya, dan masih ada siswa yang gaduh saat kegiatan pembelajaran berlangsung. Sesuai kondisi tersebut, peneliti mempersiapkan dengan matang pembelajarn pada siklus II agar dapat meningkatkan aktivitas belajar siswa.

Adapun hasil observasi pada aktivitas belajar siswa pada siklus III meningkat sangat baik, selisih persentase peningkatan antara siklus II dengan siklus III sebesar 11,5\%, dengan perolehan rata-ratanya adalah 48,2 dengan presentase 86,5\%. Aktivitas belajar siswa pada siklus III sangat baik, ditandai dengan adanya keberanian dalam bertanya dan mengemukakan pendapatnya saat berdiskusi serta kerja sama dalam kelompok untuk memecahkan masalah sudah baik. 


\section{ELSE (Elementary School Education Journal) \\ Volume 3 Nomor 1 Februari 2019 \\ P-ISSN: 2581-1800 E-ISSN: 2597-4122 \\ Email: else@um-surabaya.ac.id}

Aktivitas belajar siswa dalam pembelajaran Matematika materi perkalian dan pembagian bilangan terjadi peningkatan yang baik. Untuk lebih jelasnya nilai rata-rata aktivitas belajar siswa dapat dilihat pada Gambar 4.1 berikut ini:

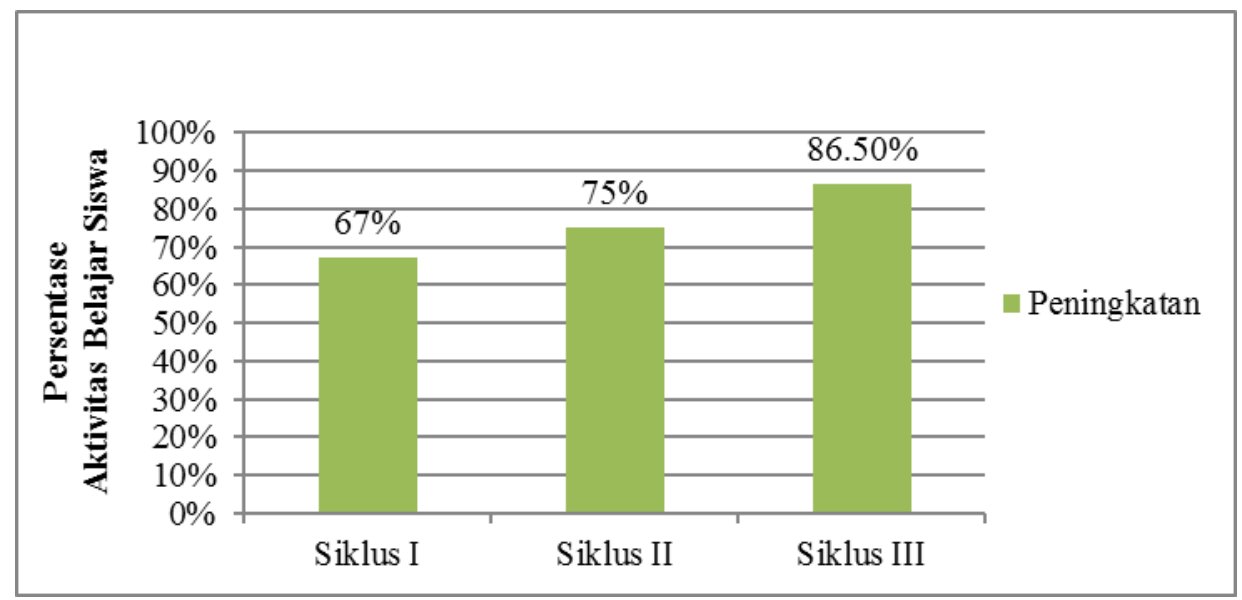

Gambar 1. Persentase Aktivitas Belajar Sis wa Tiap Siklus

Berdasarkan Gambar 1 aktivitas belajar siswa mengalami peningkatan yang signifikan. Observasi yang dilakukan oleh 2 observer diperoleh data aktivitas belajar sis wa pada siklus I $67 \%$ dan siklus II sebesar 75\%. Antara siklus I dan siklus II meningkat 8\%, dan hasil aktivitas belajar siswa pada siklus III menjadi 86,5\%. Antara siklus II dan siklus III juga mengalami peningkatan aktivitas belajar siswa sebesar 11,5\%.

2. Nilai Hasil Belajar Siswa

Hasil penelitian dilakukan melalui evaluasi yang diberikan kepada 15 siswa kelas II SDN Ajung 02 sebelum menerapkan model Problem Based Learning (PBL) dengan media Rak telur rainbow untuk meningkatkan hasil belajar materi perkalian dan pembagian mata pelajaran matematika, diperoleh rata-rata 59,77 dan ketuntasan hasil belajar siswa $27 \%$. Hal ini membuktikan bahwa tingkat pemahaman siswa terhadap pelajaran matematika materi perkalian dan pembagian bilangan siswa kelas II SDN Ajung 02 Kecamatan Ajung Kabupaten Jember Tahun Pelajaran 2017/2018 masih rendah.

Adapun data yang diperoleh dari hasil evaluasi pada siklus I setelah menggunakan model Problem Based Learning (PBL) dengan media Rak telur rainbow untuk meningkatkan hasil belajar siswa materi perkalian dan pembagian bilangan pelajaran matematika pada siswa kelas II SDN Ajung 02 Kecamatan Ajung Kabupaten Jember Tahun Pelajaran 2017/2018 mengalami peningkatan. Nilai rata-rata pada siklus I yaitu 67 
dengan ketuntasan klasikal sebesar $46 \%$. Nilai rata-rata yang diperoleh pada siklus I masih belum memenuhi kriteria KKM. Hasil belajar pada siklus I belum terjadi ketuntasan, maka perlu dilanjutkan pada siklus selanjutnya, yaitu siklus II. Untuk melanjutkan pada siklus II, perlu adanya refleksi dan pengkajian ulang terhadap kelemahan-kelemahan dan kekurangan-kekurangan yang terjadi pada proses belajar mengajar pada siklus I.

Hasil belajar siklus II diketahui bahwa nilai rata-rata kelas yang diperoleh sebesar 74 dengan ketuntasan klasikal yang dicapai sebesar 66\%. Meksipun mengalami ke naikan namun masih ada 5 siswa yang nilainya di bawah KKM. Hasil belajar pada siklus II belum mencapai KKM, maka perlu dilanjutkan pada siklus selanjutnya, yaitu siklus III. Untuk melaksanakan siklus III, perlu adanya refleksi dan pengkajian ulang terhadap kelemahankelemahan dan kekurangan-kekurangan yang terjadi pada proses belajar mengajar pada siklus II.

Hasil belajar siklus III diketahui bahwa nilai rata-rata kelas yang diperoleh sebesar 81,3 dengan ketuntasan klasikal sebesar $86 \%$. Nilai rata-rata kelas tersebut menunjukkan adanya peningkatan nilai dari siklus II ke siklus III. Hasil yang diperoleh pada siklus III telah mencapai kriteria keberhasilan yang telah ditentukan. Ada 13 siswa yang nilainya sudah mencapai KKM. Hasil belajar yang diperoleh pada siklus III membuktikan bahwa penerapan model Problem Based Learning (PBL) dengan media Rak telur rainbow dapat meningkatkan hasil belajar siswa pada pembelajaran matematika materi perkalian dan pembagian bilangan kelas II SDN Ajung 02 Kecamatan Ajung Kabupaten Jember Tahun Pelajaran 2017/2018.

Peningkatan nilai rata-rata hasil belajar siswa yang meliputi hasil data siklus I, siklus II, dan siklus III dapat dilihat pada Gambar 4.2 sebagai berikut.

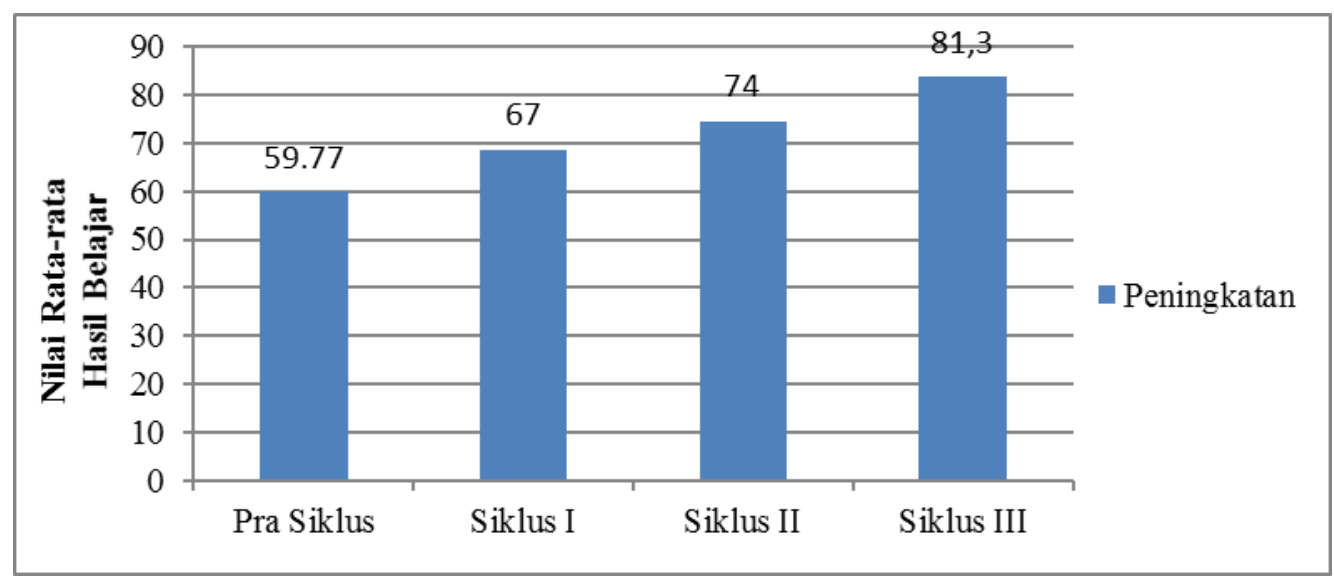

Gambar 2. Nilai Rata-Rata Sis wa 


\section{ELSE (Elementary School Education Jaurnal)}

Volume 3 Nomor 1 Februari 2019

P-ISSN: 2581-1800 E-ISSN: 2597-4122

Email:else@um-surabaya.ac.id

Berdasarkan Gambar 2 dapat disimpulkan bahwa adanya peningkatan hasil belajar siswa dalam penerapan model Problem Based Learnig (PBL) dengan media Rak telur rainbow. Hasil belajar siswa dari pra siklus, siklus I, siklus II, dan siklus III mengalami peningkatan. Peningkatan tersebut ditunjukan pada rata-rata hasil belajar siswa yaitu pada siklus I adalah 67, selisih antara pra siklus dengan, siklus I sebesar 7,23. Sedangkan pada siklus II meningkat menjadi 74 dan selisih peningkatan antara siklus I dengan siklus II adalah 7. Kemudian siklus III nilai rata-rata belajar siswa juga meningkat menjadi 81,3 dengan selisih peningkatan antara siklus II dan siklus III adalah 7.3.

3. Hasil Ketuntasan Belajar Siswa

Berdasarkan hasil penelitian yang dilakukan melalui evaluasi pada kegiatan pembelajaran matematika materi perkalian dan pembagian bilangan dengan menerapkan model Problem Based Learning (PBL) dan media Rak telur rainbow, terjadi peningkatan ketuntasan belajar siswa secara klasikal. Ketuntasan belajar pada pra sik lus, siklus I, siklus II, dan siklus III terjadi peningkatan secara signifikan. Presentase ketuntasan hasil belajar siswa secara klasikal dapat dilihat pada Gambar 4.3 sebagai berikut:

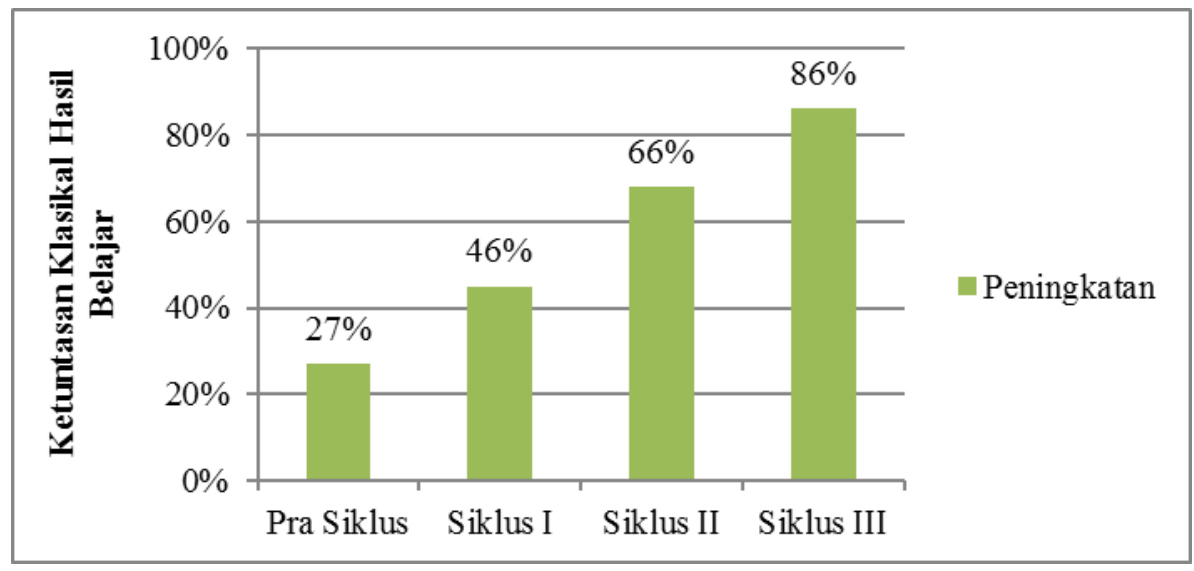

Gambar 3. Ketuntasan Hasil Belajar Siswa

Berdasarkan Gambar 3 dapat disimpulkan bahwa adanya peningkatan ketuntasan hasil belajar siswa setelah penerapan model Problem Based Learning (PBL) dengan media Rak telur rainbow. Ketuntasan hasil belajar siswa dari pra siklus, siklus I, siklus II, dan siklus III mengalami peningkatan. Peningkatan tersebut ditunjukan pada ketuntasan hasil belajar siswa pada pra siklus $27 \%$ dan meningkat ke siklus I sebesar $46 \%$, selisih dari pra siklus ke siklus I adalah 19\%. Kemudian pada siklus II menjadi 66\%, selisih antara siklus 
I ke siklus II adalah 20\%. Dan pada siklus III mengalami peningkatan sebesar $86 \%$, selisih antara siklus II dengan siklus III sebesar $20 \%$.

\section{Angket (Respon Siswa)}

Berdasarkan hasil penelitian melalui angket untuk mengetahui respon siswa setelah megikuti kegiatan pemebelajaran matematika dalam penerapan model pembelajaran Problem Based Learning (PBL) dengan media Rak telur rainbow membuktikan adanya peningkatan respon siswa pada pembelajaran matematika.

Hasil angket pada pra siklus yang menjawab "Ya" sebesar 48,33\%, "Biasa Saja" sebesar 28,33\% dan yang menjawab "Tidak" 23,33\%. Setelah melakukan kegiatan pembelajaran dengan menggunakan model Problem Based Learning hasil angket pada siklus I yakni, yang menjawab "Ya" sebesar 56,6\%," "Biasa Saja" 23,1\% dan yang menjawab "Tidak" sebesar 20\%. Berdasarkan data tersebut masih banyak siswa tidak tertarik dengan kegiatan pembelajaran Matematika. Sesuai dengan data dan kondisi tersebut, maka peneliti mempersiapkan dengan matang pembelajaran pada siklus II agar dapat meningkatkan respon siswa pada pembelajaran matematika.

Hasil angket pada siklus II menjawab "Ya" sebesar 66,67\%, "Biasa Saja" sebesar 22,78\%, dan yang menjawab "Tidak" 11,11\%. Hasil angket pada siklus II mengalami peningkatan, namun ada sebagian siswa yang kurang tertarik untuk mengikuti kegiatan pembelajaran matematika. Sesuai dengan data dan kondisi tersebut, maka peneliti mempersiapkan dengan matang pembelajaran pada siklus III agar dapat meningkatkan respon siswa pada pembelajaran matematika.

Hasil angket pada siklus III mengalami peningkatan yang sangat baik. Adapun hasil angket pada siklus III yang menjawab "Ya" sebesar 71,6\%, "Biasa Saja" 22,78\%, dan yang menjawab "Tidak" sebesar 6,11\%.

Hasil angket yang positif menjawab "Ya" pada pra siklus sebesar 48,33\% dan pada siklus I yang merespon "Ya" atau yang menjawab positif yakni 56,6\%. Selisih antara pra siklus dengan siklus I peningkatannya sebesar 8,27\%. Pada siklus II menjadi 66,67\%, antara siklus I dan siklus II mengalami peningkatan sebesar $10.07 \%$. Dan hasil angket pada siklus III juga mengalami peningkatan sebesar 4,93\%, sehingga hasil angket pada siklus III yang positif menjawab "Ya" sebsesar 71,6\%. 


\section{ELSE (Elementary Schuol Education Journal)}

Volume 3 Nomor 1 Februari 2019

P-ISSN: 2581-1800 E-ISSN: 2597-4122

Email:else@um-surabaya.ac.id

\section{KESIMPULAN DAN SARAN}

\section{Kesimpulan}

Berdasarkan analisis data penelitian di kelas II SDN Ajung 02 Kecamatan Ajung Kabupaten Jember Tahun Pelajaran 2017/2018 dengan penerapan model Problem Based Learning (PBL) melalui media Rak telur rainbow pada mata pelajaran Matematika materi perkalian dan pembagian bilangan, maka dapat disimpulkan bahwa:

1. Aktivitas belajar siswa dari siklus I, siklus II, dan siklus III mengalami peningkatan. Hasil aktivitas belajar siswa pada siklus I yakni 67\%, dan pada siklus II menjadi $75 \%$. Terjadi peningkatan pada siklus I ke siklus II sebesar 8\%. Kemudian pada siklus III aktivitas belajar siswa meningkat menjadi $86,5 \%$, selisih peningkatan pada siklus II ke siklus III adalah $11,5 \%$.

2. Hasil belajar matematika siswa dari siklus I, siklus II, dan siklus III mengalami peningkatan. Pada siklus I rata-rata hasil belajar siswa 67 dengan ketuntasan klasikal $46 \%$ dalam kategori tidak tuntas. Kemudian pada siklus II rata-ratanya menjadi 74 dengan ketuntasan klasikal 66\% dalam kategori tidak tuntas, dan pada siklus III terjadi peningkatan yang sangat baik rata-rata hasil belajar menjadi 81,6 dengan ketuntasan kelas $86 \%$ dalam kategori tuntas.

3. Respon siswa dari siklus I, siklus II, dan siklus III mengalami peningkatan. Hasil angket pada siklus I meningkat menjadi 56,6\%, dan pada siklus II meningkat menjadi $66,67 \%$, pada siklus III meningkat menjadi 71,6\%.

Jadi, penerapan model Problem Based Learning dengan menggunakan media Rak telur rainbow pada mata pelajaran matematika kelas II SDN Ajung 02 dapat meningkatkan aktivitas belajar dan respon belajar siswa, sehingga hasil belajar siswa juga ikut meningkat.

\section{Saran}

Berdasarkan hasil penelitian yang diperoleh dari uraian sebelumnya agar penguasaan materi perkalian dan pembagian bilangan oprimal bagi siswa, maka disampaikan saran sebagai berikut.

1. Manfaat teoritis

Secara teoritis hasil penelitian ini dapat bermanfaat sebagai berikut:

a. Sebagai salah satu alternatif untuk meningkatkan penguasaan materi perkalian dan pembagian bilangan. 


\section{ELSE (Elementary School Education Journal)}

Volume 3 Nomor 1 Februari 2019

P-ISSN: 2581-1800 E-ISSN: 2597-4122

Email: else@um-surabaya.ac.id

b. Sebagai pijakan untuk mengembangkan penelitian-penelitian yang menggunakan model pembelajaran Problem Based Learning (PBL) dengan media Rak telur rainbow.

2. Manfaat praktis

Secara praktis penelitian ini dapat bermanfaat sebagai berikut.

a. Bagi guru, sebagai bahan masukan atau pertimbangan dalam upaya meningkatkan penguasaan materi perkalian dan pembagian bilangan.

b. Bagi peneliti, sebagai pengalaman untuk terjun dalam dunia pendidikan dan memperdalam ilmu pengetahuan tentang pelaksanaan pembelajaran menggunakan model Problem Based Learning (PBL) dengan media Rak telur rainbow.

c. Bagi siswa, untuk memberikan kesempatan bagi siswa untuk lebih aktif serta lebih paham tentang materi yang diajarkan oleh guru, dapat menciptakan suasana pembelajaran yang menyenangkan, melatih siswa agar berani untuk mengemukakan pendapat atau membuat soal pertanyaan, dan dapat meningkatkan kerjasama siswa dalam kelompok serta dapat meningkatkan kemampuan bersosialisasi siswa.

d. Bagi sekolah, sebagai bahan informasi bagi sekolahan dalam upaya peningkatan mutu pendidikan matematika.

\section{DAFTAR PUSTAKA}

Arikunto, Suharsimi, dkk 2015. Penelitian Tindakan Kelas. Jakarta: Bumi Aksara.

Aqib, Zainal, dkk. 2011. Penelitian Tindakan Kelas untuk Guru SD, SLB dan TK. Bandung: CV. Yrama Widya.

Fauzi, Rohmad. 2014. Penerapan Model Problem Based Learning untuk Meningkatkan Hasil Belajar Siswa Kelas IV SD Negeri 01 Metro Barat. Universitas Lampung. Bandar Lampung.

Hamalik, Oemar. 2010. Proses Belajar Mengajar. Jakarta: Bumi Aksara.

Heruman. 2008. Model Pembelajaran Matematika di Sekolah Dasar. Bandung: PT.Refika Adiatma. 